\title{
Mobile Based Learning and Examination: Students and Instructors Perceptions from Different Arab Countries
}

\author{
Ayham Fayyoumi ${ }^{1}$, Heba Mohammad ${ }^{1}$, Hossam Faris $^{2}$ \\ ${ }^{1}$ Department of Information Systems, Al-Imam Muhammad ibn Saud Islamic University, Riyadh, KSA; ${ }^{2}$ Department of Business \\ Information Technology, The University of Jordan, Amman, Jordan. \\ Email: a.fayyoumi@ccis.imamu.edu.sa,hkmohammad@ccis.imamu.edu.sa,hossam.faris@ju.ed.jo
}

Received November $20^{\text {th }}, 2013$; revised December $11^{\text {th }}, 2013$; accepted December $18^{\text {th }}, 2013$

Copyright (C) 2013 Ayham Fayyoumi et al. This is an open access article distributed under the Creative Commons Attribution License, which permits unrestricted use, distribution, and reproduction in any medium, provided the original work is properly cited. In accordance of the Creative Commons Attribution License all Copyrights (C) 2013 are reserved for SCIRP and the owner of the intellectual property Ayham Fayyoumi et al. All Copyright (c) 2013 are guarded by law and by SCIRP as a guardian.

\begin{abstract}
The online education market is expanding both globally and locally; Arab countries are paying special attention to the growth of this sector. Reports showed that the e-learning market arrived at \$27.1 billion in the year 2009 and is expected to surpass $\$ 49.6$ billion by the year 2014. This paper presents and surveys the perception of students and instructors regarding mobile learning and mobile examination system in some Arab countries. Many universities in the Arab world are under progress in the implementation of this new technology and many have already implemented it. Strong tools are required to improve e-learning system of education. This research supports the transition of education from conventional methods to m-learning and m-exam systems. The purpose of this research is to study the perception of both instructors and students regarding mobile learning and mobile examination systems. The introduction of such systems to the educational process requires people involved to have basic technical skills and to be aware of the benefits of such systems. Results showed different perspectives from three countries; also showed that online examination systems could be very helpful, but many factors should be considered and they should be implemented carefully to guarantee the successful adoption, fairness and reliability.
\end{abstract}

Keywords: m-Learning; Mobile Based Exam System; m-Examination Fairness; Instructors Attitude towards m-Exam; Students Perception of m-Exam

\section{Introduction}

The advancement in the field of communication and information technologies has created new opportunities especially in the field of education [1] (Shehabat \& Mahdi, 2009). Online learning is gradually being implemented by almost every country in the world because technology in education not only provides students to organize their learning but also provides them access to large quantity of information over which teacher has no control [2] (Salah, 2009: pp. 221-229). The use of information technology including web based technology is increasing rapidly in education; web based education provides students with extra knowledge; this technology is used in many ways including web based learning [3] (Fahad, 2009).

\section{Mobile Learning and Mobile Exam System}

In the last few years the emergence of online learning has been influenced by the rapid changes in higher education, including the establishment of new universities and support given for the integration of online learning [4] (Alebaikan, 2012). Moreover, rapid growth and development of technology has opened new ways of teaching and learning, education by the help of technology is being delivered to students in many areas; many countries are finding different ways to fulfil the academic demands of increasing population [5] (Alkhalaf, Drew, \& Alhussain, 2012: pp. 98-104). In many countries, technology is being used to impart distance education and to make education available to everyone; specialized courses are 
also being taught by this method [6] (Tarhini, Hone, \& Liu, 2013). The ways in which online education is implemented differ noticeably from region to region. Such programs are particularly beneficial for many people who are not economically, physically or geographically able to achieve traditional education [7] (Milani, 2008: pp. 149-150).

Mobile learning is a technology that uses wireless communication to support the transmission of educational content (test, video, voice, or multimedia) to mobile devices that provide freedom of time and location, it represents two main characteristics of mobile wireless technology that is reachability and mobility [8] (Almekhlafi \& Almeqdadi, 2010: pp. 165-175). The point which must be kept in mind is that, almost all mobile network providers in the Arab world are providing commercial packages that offer broad band internet connection for mobile devices in very economical and affordable prices [9] (Olufemi, 2008: pp. 53-66).

Mobile based exam system is not declared as the perfect system, because of its own advantages and disadvantages [10] (Ruth Stephen, 2010: pp. 78-82). This research paper talks about the perceived usefulness of m-learning and mobile examination system among instructors and students, this paper also provides a quantitative research study that examines the collected data regarding mobile exam system. Two questionnaires were developed and were sent to the instructors and students (males and females) in the Arab region, this survey included some universities from three Arab countries namely Jordan, United Arab Emirates, Saudi Arabia.

\section{Methodology}

Two questionnaires has been developed and distributed to the students and faculty of different colleges/universities at the three Arab countries (United Arab Emirates, Jordan, and Saudi Arabia. Two educational institutes from each of the above mentioned countries were selected and from each country 100 students (50 male and 50 female) and 30 faculty members (15 male and 15 female) were selected randomly for the survey. Response rate was very acceptable, about $62 \%$ of students and about $90 \%$ of faculty have responded.

The questionnaire comprised of three sections, first part was related to the demographic questions such as age, gender, college/university, teaching experience, discipline. In the second part computer and internet literacy of the instructor and student were tested and the third part included the perception of students and instructors regarding m-learning and m-examination.

\section{Instructors Survey Results}

Two educational institutes from each of the above men- tioned three countries were examined and the following results were retrieved.

\subsection{Computer Literacy of the Instructors}

The second section of the questionnaire was related to the computer literacy of the faculty. Results show that $95 \%$ of the respondents are having personal computer (PC), 92\% of the respondents are having email address, and only $32 \%$ of the respondents are having website. Only $14.4 \%$ faculty had previously taught a course through mobile devices (including laptops). In terms of computer usage, $59.3 \%$ of the faculty members responded that they use computer more than three hours in a day, $5.9 \%$ of the faculty members responded that they do not use computer, $7.6 \%$ of the faculty responded that they use computer 1 - 2 hours in a week and $27.1 \%$ responded that they use computer $1-2$ hours in a day. $42.4 \%$ of the faculty members responded that they use internet more than three hours in a day and $6.8 \%$ replied that they do not use internet, 5.9\% replied that they use internet 1 - 2 hours in a week and $44.9 \%$ replied that they spend 1 - 2 hours in a day using internet (Table 1).

Results show that $39 \%$ of the teachers surveyed said that they use computers or the internet to create or upload instructional materials, 34\% responded that they use computers or the internet for administrative record keeping, and less than $10 \%$ reported that they access computers and internet to find model lesson plans and to access research and best practices.

\subsection{Attitude of Faculty towards Mobile Based Exam System and $m$-Learning}

Third part of the questionnaire was related to the perception of the instructors/faculty members related to the mobile examination system and m-learning method, for this part of the questionnaire, a five-point Likert scale criteria was used, where 1 = totally agree, 2 = agree, 3 = no idea, $4=$ disagree and $5=$ totally disagree. Survey showed that $55.1 \%$ of the total faculty members of all the three countries (Jordan, United Arab Emirates, and Saudi Arabia) regarded that m-learning and mobile examination will

Table 1. Computer literacy of faculty at educational institutes of Arab countries.

\begin{tabular}{cccc}
\hline \multicolumn{2}{c}{ Faculty Computer Usage } & \multicolumn{2}{c}{ Faculty Internet Usage } \\
\hline Hours & $\%$ & Hours & $\%$ \\
\hline I do not use it & 5.9 & I do not use it & 6.8 \\
1 - 2 in a week & 7.6 & 1-2 in a week & 5.9 \\
1 - 2 in a day & 27.1 & 1-2 in a day & 44.9 \\
3+ in a day & 59.3 & 3+ in a day & 42.4 \\
\hline
\end{tabular}


make a qualitative help in the process of learning and teaching students. $84 \%$ of the faculty members agreed that it will increase the self learning process of students. $39.9 \%$ of the faculty members declared that it will make students' evaluation more difficult. However, $83 \%$ of the faculty members who showed their interest in mobile examination system and m-learning were of age 43 or below (Table 2).

Moreover, according to the instructors; m-learners should have many characteristics, for instance, being able to learn independently in isolation with positive view towards learning. Moreover, they should have good computer and internet skills and must be able to make the best use of time. Also, they must be self-disciplined and should enjoy working and studying alone.

In addition, faculty involved in mobile based teaching must have some capabilities; such as, being proficient in using computer/mobile devices and internet. Also, they should have interest to integrate themselves and students with technology, and should be able to deliver lecture through any media which involves technology.

\section{Students Survey Results}

Students were also surveyed in the same manner as the instructors. The second part of the survey was related to the computer literacy among the students of the three countries.

\subsection{Computer Literacy among the Students}

Results show that $97 \%$ of the surveyed students of the three Arab countries are having personal computer (PC), $96 \%$ of the respondents are having email address and only $11 \%$ of the student are having website. $62.4 \%$ of the surveyed students responded that they use computer more than three hours a day, $1.3 \%$ said that they do not use computer, $6.2 \%$ replied that they use computer 1 - 2

Table 2. Perception of faculty at educational institutes of Arab countries regarding m-learning and mobile exam system.

\begin{tabular}{cccc}
\hline Respond & $\begin{array}{c}\text { Ease in } \\
\text { learning }\end{array}$ & $\begin{array}{c}\text { Students evaluation } \\
\text { will become difficult }\end{array}$ & Qualitative help \\
\hline $\begin{array}{c}\text { Totally } \\
\text { disagree }\end{array}$ & $9.3 \%$ & $19 \%$ & $6.8 \%$ \\
Disagree & $21.2 \%$ & $24.3 \%$ & $21.2 \%$ \\
No idea & $15.3 \%$ & $17.8 \%$ & $16.9 \%$ \\
$\begin{array}{c}\text { Agree } \\
\text { Totally } \\
\text { agree }\end{array}$ & $31.4 \%$ & $19.9 \%$ & $31.4 \%$ \\
Total & $100 \%$ & $20 \%$ & $23.7 \%$ \\
\hline
\end{tabular}

hours in a week and $30.1 \%$ replied that they use computer 1 - 2 hours in a day. $59.4 \%$ of the students answered that they use internet more than three hours in a day, $46.6 \%$ answered that they use internet $1-2$ hours in a day, $10.6 \%$ responded that they use internet $1-2$ hours in a week and 2.2\% replied that they do not use internet (Table 3).

\subsection{Attitude of Students towards Mobile Based Exam System and m-Learning}

Data obtained shows that $70 \%$ of the students agreed on the point that their learning skills are enhanced through m-learning. $60 \%$ of the students claimed that mobile examination is useful, $96 \%$ of the students agreed on the fact that m-learning is very useful and is very helpful for those students who live at remote areas and cannot attend the university or educational institute daily. $19.3 \%$ of the students responded that this way of examination will not be fair. It is also observed that students use internet and computer more than teachers (Table 4).

\section{Additional Analysis and Data Variations}

\subsection{Variation of Data with Countries}

Perception of instructors/faculty members and students obtained at the three Arab countries was almost similar to each other with only slight differences in the percentages of the level of interest in m-learning and mobile examination (Table 5).

Table 3. Computer literacy of university students of Arab countries.

\begin{tabular}{cccc}
\hline \multicolumn{2}{c}{ Student Computer Usage } & \multicolumn{2}{c}{ Student Internet Usage } \\
\hline Hours & $\%$ & Hours & $\%$ \\
\hline I do not use it & 1.3 & I do not use it & 2.2 \\
1 - 2 in a week & 6.2 & 1 - 2 in a week & 10.6 \\
1 - 2 in a day & 30.1 & 1 - 2 in a day & 46.6 \\
3+ in a day & 62.4 & 3+ in a day & 59.4 \\
\hline
\end{tabular}

Table 4. Perception of university students of Arab countries regarding $\mathrm{m}$-learning and mobile exam system.

\begin{tabular}{ccc}
\hline Respond & $\begin{array}{c}\text { Enhanced learning } \\
\text { Skills }\end{array}$ & $\begin{array}{c}\text { Usefulness of } \\
\text { Examination }\end{array}$ \\
\hline Totally disagree & $4.1 \%$ & $9.2 \%$ \\
Disagree & $9.3 \%$ & $10.1 \%$ \\
No Idea & $16.6 \%$ & $20.7 \%$ \\
Agree & $50.2 \%$ & $49.6 \%$ \\
Totally agree & $19.8 \%$ & $10.4 \%$ \\
Total & $100 \%$ & $100 \%$ \\
\hline
\end{tabular}


Table 5. Perception of m-learning among students and instructors at different Arab countries.

\begin{tabular}{cccccc}
\hline & Faculty & & \multicolumn{2}{c}{ Students } \\
\hline Country & $\begin{array}{c}\text { \% Preferred } \\
\text { m-Learning }\end{array}$ & $\begin{array}{c}\text { \% favoured Mobile } \\
\text { Based Exam }\end{array}$ & Country & \% Preferred m-Learning & $\begin{array}{c}\text { \% favoured Mobile } \\
\text { Based Exam }\end{array}$ \\
\hline Jordan & 50.3 & 19.4 & Jordan & 73.2 & 43.1 \\
United Arab Emirates & 50.9 & 19.6 & United Arab Emirates & 76.3 & 43.8 \\
Saudi Arabia & 50.5 & 19.3 & Saudi Arabia & 70.6 & 43.3 \\
\hline
\end{tabular}

It can be seen from the table that the survey results of the instructors/faculty members and students of the three countries regarding this new technology is almost similar, if we neglect the slight differences so we can analyze that almost $50 \%$ of the faculty in all of these countries favoured m-learning. We can also say that an average more that $80 \%$ teachers were not in the favour of mobile based exam system. Moreover, from the data it is clear that the faculty of United Arab Emirates (UAE) were slightly more in favour of m-learning.

It can be seen from the data of the students that the students of the United Arab Emirates (UAE) passionate to embrace this new technology, there is a similarity between the thoughts of the students of Jordan and Saudi Arabia. The lowest percentage regarding the preference of this new technology among students is in Jordan, but data is not varying too much.

\subsection{Variation of Data with Gender}

There is also variation in data with respect to the gender; it is observed that the perception of female respondents was different from that of the male respondents (Tables 6 and 7).

From the above data we can observe that the percentage of computer usage and internet usage among the male respondents is more than that of the female respondents, the reason behind this may be cultural and/or social factors, which plays a vital role in this regard. 69.3\% of the male students use computer more than three hours in a day, whereas only $49.2 \%$ of female students use computer more than three hours in a day. Same case is with faculty members, $64.3 \%$ of the male instructors use computer more than three hours in a day, whereas only $53.4 \%$ of the female instructors use computer more than three hours in a day.

\subsection{Unfairness of Mobile Examination}

The issue of mobile learning and mobile based exams in particular, is a hot topic. Many universities are striving to put the regulations and rules to manage and guarantee the fairness and successful implementation of such environments. We have examined wither or not there is an asso- ciation between the unfairness of the mobile examination form one side, and the role (instructor/student) and gender of instructor and students from the other side.

In view of the chi-square tables (Tables 8 and 9), it is noted that the level of significance is more than 0.05 that is 0.109 reflecting that there is no association between gender of students and their perception of mobile examination unfairness. Moreover, it is clear that the level of significance is above 0.05 that is 0.742 indicating that there is no association between gender of instructors and mobile examination unfairness.

However, when looking at the association between the role of people involved (instructor or student) and the mobile examination unfairness, we found that the significance level is less than 0.05 that is 0.042 showing that there is association between the role and mobile examination unfairness. Therefore, role (instructor/student) is related to mobile exam unfairness.

This might motivate us to investigate this issue in more details. In fact, the development of a reliable and trusted mobile exam systems is important. Moreover, the understanding the factors that impact its successful implantation and reliability is significant, in particular in the context of the Arab countries (Table 10).

\section{Research Findings}

Data collected from the questionnaire was analysed using the statistical software SPSS 14.0, the statistical analysis of the data collected showed many findings related to the perception of instructors/faculty members regarding to mobile based exam system. Findings are summarized as follows:

1) Computer competency

Familiarity with computer technology plays an important role in forming the attitudes of faculty/instructors and student towards the m-learning and m-examination method. There is a strong relationship between the level of computer competency and acceptance of m-learning. The age of faculty may be a factor in the association between computer technology literacy and the level of reluctance to accept any mode of m-learning.

2) Lack of incentives and technological infrastructure

Results clearly indicate that one factor which is be- 
Table 6. Percentage of computer usage and internet usage among male and female students.

\begin{tabular}{cccccc}
\hline \multicolumn{2}{c}{ Male students } & \multicolumn{3}{c}{ Female students } \\
\hline Hours & Internet \%age & Computer \%age & Hours & Internet \%age & Computer \%age \\
\hline I do not use it & 3.1 & 0.5 & I do not use it & 7.1 & 5.0 \\
$1-2$ in a week & 5.2 & 5.1 & $1-2$ in a week & 9.2 & 12.1 \\
1-2 in a day & 24.5 & 25.1 & $1-2$ in a day & 40.2 & 33.7 \\
3+ in a day & 67.2 & 69.3 & 3+ in a day & 43.5 & 49.2 \\
\hline
\end{tabular}

Table 7. Percentage of computer usage and internet usage among male and female instructors.

\begin{tabular}{cccccc}
\hline & Male Instructors & \multicolumn{3}{c}{ Female Instructors } \\
\hline Hours & Internet \%age & Computer \%age & Hours & Internet \%age & Computer \%age \\
\hline I do not use it & 3.9 & 5.7 & I do not use it & 6.4 & 5.6 \\
1 -2 in a week & 5.8 & 5.8 & $1-2$ in a week & 10.1 & 8.9 \\
1-2 in a day & 42.9 & 23.1 & $1-2$ in a day & 40.3 & 32.1 \\
$3+$ in a day & 47.4 & 64.3 & $3+$ in a day & 43.2 & 53.4 \\
\hline
\end{tabular}

Table 8. Chi-square test (Students gender * Unfairness of mobile exam).

\begin{tabular}{|c|c|c|c|c|c|}
\hline \multicolumn{6}{|c|}{ Chi-Square Tests } \\
\hline & Value & $\mathrm{df}$ & Asymp. Sig. (2-sided) & Exact Sig. (2-sided) & Exact Sig. (1-sided) \\
\hline Pearson Chi-Square & $2.566^{\mathrm{a}}$ & 1 & 0.109 & & \\
\hline Continuity Correction $^{\mathrm{b}}$ & 1.715 & 1 & 0.190 & & \\
\hline Likelihood Ratio & 2.611 & 1 & 0.106 & & \\
\hline Fisher's Exact Test & & & & 0.148 & 0.095 \\
\hline Linear-by-Linear Association & 2.514 & 1 & 0.113 & & \\
\hline $\mathrm{N}$ of Valid Cases & 186 & & & & \\
\hline
\end{tabular}

${ }^{\mathrm{a}} 0$ cells $(0.0 \%)$ have expected count less than 5 . The minimum expected count is 8.74 . ${ }^{\mathrm{b}}$ Computed only for a $2 \times 2$ table.

Table 9. Chi-square test (Instructor gender * Unfairness of mobile exam).

\begin{tabular}{cccccc}
\hline & \multicolumn{5}{c}{ Chi-Square Tests } \\
\hline & Value & df & Asymp. Sig. (2-sided) & Exact Sig. (2-sided) & Exact Sig. (1-sided) \\
\hline Pearson Chi-Square & $0.110^{\mathrm{a}}$ & 1 & 0.740 & \\
Continuity Correction ${ }^{\mathrm{b}}$ & 0.001 & 1 & 0.980 & 0.767 & 0.487 \\
Likelihood Ratio & 0.110 & 1 & & \\
Fisher's Exact Test & & & 0.742 & \\
Linear-by-Linear Association & 0.108 & 1 & & \\
N of Valid Cases & 81 & & & \\
\hline
\end{tabular}

${ }^{\mathrm{a}} 0$ cells $(0.0 \%)$ have expected count less than 5 . The minimum expected count is $6.46 .{ }^{\mathrm{b}}$ Computed only for a $2 \times 2$ table. 
Table 10. Chi-square test (Role * Unfairness of mobile exam).

\begin{tabular}{|c|c|c|c|c|c|}
\hline \multicolumn{6}{|c|}{ Chi-Square Tests } \\
\hline & Value & df & Asymp. Sig. (2-sided) & Exact Sig. (2-sided) & Exact Sig. (1-sided) \\
\hline Continuity Correction ${ }^{\mathrm{b}}$ & 3.075 & 1 & .080 & & \\
\hline Likelihood Ratio & 4.229 & 1 & .040 & & \\
\hline Fisher's Exact Test & & & & .052 & .039 \\
\hline Linear-by-Linear Association & 4.071 & 1 & .044 & & \\
\hline $\mathrm{N}$ of Valid Cases & 267 & & & & \\
\hline
\end{tabular}

${ }^{\mathrm{a}} 0$ cells $(0.0 \%)$ have expected count less than 5 . The minimum expected count is 10.58 . ${ }^{\mathrm{b}}$ Computed only for a $2 \times 2$ table.

coming a barrier for instructors in the adoption of the mobile exam system and m-learning is the lack of incentives and technological infrastructure. Faculty members also commented that qualified staff is not available at the lab for help.

3) Mode of m-learning

Survey showed that majority of the teachers' preferred m-learning system in combination with traditional method of teaching and evaluation, most of the teachers expressed their views that technology is a great tool in m-learning but human factor would always be present in teaching and evaluation of students.

Majority of the students of Arab countries showed their interest in this technology, but this interest is not for all the disciplines, the students of engineering, medicine and accounting were not much interested in m-learning and mobile exam system, they preferred class room teaching rather than online learning because according to them these subjects are relatively tough and requires practical training and to properly understand it instructor must be present physically for support and guidance.

4) Advantages and disadvantages

This technology is a great tool in learning and teaching process, instructors declared that m-learning promotes self learning, increases the learning quality, and makes the process of teaching easy, flexible and provides them access to vast information.

Teachers also commented that through this technology they can deliver their point of view to students in less time and with more clarification [11] (Burgess, 2008: pp. 131-138).

Most of the instructors accepted the fact that m-learning and mobile exam system would reduce the time which is consumed in checking and assessing of students copies manually.

Female students of these countries regarded m-learning system as an ideal system for females who cannot attend the university/college daily.
5) Mobile examination system

Most of the teachers were not in the favour of mobile examination system because according to them, students cannot be properly evaluated or judged through this process, some teachers who supported mobile examination said that this system would reduce the practice of cheating and favouritism in examination [12] (Patel and Aghayere Oct 2006). However, many others believed that it is unfair method of testing would increase the risk of cheating, unless some factors are taken into consideration; for instance, that every student gets different questions.

6) Age factor

Results indicate that there is also an age factor involved in the acceptance of this technology; it is observed that faculty members who were of age 45 or below were more passionate to accept this technology as compared to those who were above 45 ; this clearly indicates that older faculty members are reluctant to accept this new technology [13] (Elango \& Selvam, 2008: pp. 31-104).

7) Self confidence

It is observed that most of the teachers and students are confident enough to relate their education with technology, according to majority of them; implementation of this new technology is not a difficult job, according to them lack of facilities and awareness is a major factor that is acting as a barrier in the adoption of this technology.

\section{8) Awareness}

The point which is very much clear from the survey is that most of the teachers and students are unaware of the concept of m-learning. The proof of this finding is that $16.6 \%$ of the students are having no idea that whether m-learning would enhance skills or not and $20.7 \%$ of the students are having no concept about mobile based exam. $15.3 \%$ of the faculty members are having no idea that whether it will create ease in learning or not.The belief which is common in almost every respondent is that 
m-learning is related to the use of computers and websites only and very few were fully aware about the benefits, outcomes and usage of the mobile based learning and examination process. It is also seen that the students and faculty members who are not very proficient in the computer applications and internet usage are not in favour of mobile based examination system and m-learning [14] (Kahiigi et al., 2008: pp. 77-88).

\section{Conclusions}

This study shows clearly that within the study context a considerable number of instructors and students consider m-learning to be synonymous with technology. The real academic drive behind m-learning is to analyse and use technology as a tool to serve educational purposes. The economics involved in teaching online courses usually include higher production costs depending on the difficulty of the topic and the media used for example HTML pages, streaming-video presentation, flash animation and interactive content.

The study suggests that cultural elements can play a significant role in making positive attitudes of faculty and student towards m-learning. A significant number of students and faculty members believe that Arab culture, institutions, and societies are ready for the m-learning model of teaching. Therefore, any educational strategy that intends to embed m-learning into the educational system should add this point of view into consideration. Furthermore, this study shows that computer literacy among faculty members acts as a barrier in the implementation and popularization of the m-learning model at Arab countries. The major barrier that is faced with the m-learning model at Arab universities seems to be lack of academic vision behind the acceptance of the m-learning model. Success in the implementation of this technology can only be achieved by proceeding and seeking instructive and pedagogical approach. It is clear that m-learning and mobile examination system will not prosper in Arab countries until and unless both faculty and students are well prepared. Policies, rules and regulations at the universities of Arab countries must adjust to the changes brought about by this new technology. Moreover, incentives should be given to faculty who want to teach and implement the m-learning model. Arab universities should revise their policies and steps must be taken to create awareness regarding this technology among both students and instructors.

In three Arab countries including Saudi Arabia, United Arab Emirates (UAE), and Jordan, and maybe in many others, these technologies are still in its developing phase and can be used as a tool that can be strategically used to improve student and faculty relation.

\section{Recommendations}

Based on the above findings, it is recommended that following steps must be taken to enhance teachers' and students' abilities and competencies with regard to mobile based exam system.

1) To adopt this technology, interest regarding computer and internet among the respondents must be developed, because it is seen from the survey that respondents who use internet and computer more showed greater interest in technology as compared to those who make use of computer and internet relatively less.

2) Awareness among the respondents should be created regarding this new technology, since the acceptance of this new technology by instructors and students is based on their awareness. Moreover, workshops and seminars must be organized at the university and college level to enhance instructor, student and technology integration.

3) Teachers should be provided with the facilities including hardware and software, this should also be trained to the students. In addition, faculty should be provided with some release time so that they could practice and plan about the integration of technology with students at the class room.

4) Faculty and students should be encouraged, teachers should be provided with incentives for proper integration of technology in the classrooms. Moreover, technology integration in relationship to curriculum goals and outcomes should also be investigated.

5) Effects of technology integration on students' achievement and attitude should be investigated and proper steps should be taken.

6) Online examination systems could be very helpful, but many factors should be considered and they should be implemented carefully to guarantee the successful adoption, fairness and reliability.

\section{REFERENCES}

[1] S. Issa and M. Saad, "E-Learning and Its Impact to the Educational System in the Arab World,” International Conference on Information Management and Engineering, IEEE, 2009.

[2] S. Al-Fadhli, "Instructor Perceptions of E-Learning in an Arab Country: Kuwait University as a Case Study,” ELearning and Digital Media, Vol. 6, No. 2, 2009, pp. 221-229. http://dx.doi.org/10.2304/elea.2009.6.2.221

[3] N. Fahad, "Students' Attitudes and Perceptions towards The Effectiveness of Mobile Learning in King Saud University, Saudi Arabia," The Turkish Online Journal of Educational Technology, Vol. 8, No. 2, 2009, Article ID: 10.

[4] R. A. Alebaikan, "The Future of Blended Learning," World Academy of Science, Engineering and Technology, 
Vol. 63, 2012, pp. 484-488.

[5] A. Salem, D. Steve and A. Thamer, "Assessing the Impact of e-Learning Systems on Learners: A Survey Study in the KSA," Procedia-Social and Behavioral Sciences, Vol. 47, 2012, pp. 98-104.

[6] T. Ali, H. Kate and X. H. Liu, "Factors Affecting Students' Acceptance of e-Learning Environments in Developing Countries: A Structural Equation Modeling Approach," International Journal of Information and Education Technology, Vol. 3, No. 1, 2013, pp. 54-59.

[7] M. Manuela, "Cultural Impact on Online Education Quality Perception,” The Electronic Journal of e-Learning, Vol. 6, No. 2, 2008, pp. 149-160.

[8] A. G. Almekhlafi and F. A. Almeqdadi, “Teachers' Perceptions of Technology Integration in the United Arab Emirates School Classrooms,” Educational Technology \& Society, Vol. 13, No. 1, 2010, pp. 165-175.

[9] O. Olufemi, "Pedagogical Approaches and Technical Subject Teaching through Internet Media," The Elec- tronic Journal of e-Learning, Vol. 6, No. 1, 2008, pp. 5366.

[10] R. Stephen, "Is E-Learning Really Working? The Trillion-Dollar Question,” IEEE Computer Society, 2010, pp 78-82.

[11] J. Burgess, "Is a Blended Learning Approach Suitable for Mature, Part-time Finance Students?” The Electronic Journal of e-Learning, Vol. 6, No. 2, 2008, pp. 131-138.

[12] P. Jimmy and A. Abi, "Students' Perspective on the Impact of a Web-Based Discussion Forum on Student Learning,” IEEE Computer Society, 2006.

[13] R. Elango, V. K. Gudep and M. Selvam, "Quality of eLearning: An Analysis Based on e-Learners' Perception of e-Learning," The Electronic Journal of e-Learning, Vol. 6, No. 1, 2008, pp. 31-44.

[14] E. K. Kahiigi, et al., "Exploring the e-Learning State of Art,” The Electronic Journal of e-Learning, Vol. 6, No. 2, 2008, pp. 77-88. 